\title{
Role of rooting hormone on root induction of Tecoma stans semi-hardwoodcuttings
}

\author{
Dr. A.D. Ashok* \\ *Assistant Professor (Horticulture),Institute of Agriculture, Tamil Nadu Agricultural University, \\ Kumulur - 621712, Trichy
}

\begin{abstract}
The experiment was conducted at Institute of Agriculture, Tamil Nadu Agricultural University, Kumulur, Tiruchirappalli district of Tamilnadu, India. The experiment was laid out in Completely Randomized Block Design (FCRD) with 2 replications, including seven treatments of various concentration of NAA solutions viz., 500 ppm, 1000 ppm, 1500 ppm, 2000 ppm, 2500 ppm, 3000 ppm and control (without any treatment). Semi-hardwood cuttings of Tecoma stans were treated in quick dip method for 30 seconds and planted under mist chamber for rooting. Minimum days of sprouting (9.90 days), higher rooting percentage $(80.90 \%)$ and maximum root length $(16.75 \mathrm{~cm})$ were recorded in $3000 \mathrm{ppm}$ concentration of NAA. We conclude from this experiment that quick dipping for 30 seconds with $3000 \mathrm{ppm}$ of NAA will promote earlier rooting, maximum rooting percentage and improved root growth in propagation through rooting of Tecoma stans semi hardwood cuttings under mist chamber conditions of semi-arid tropical region.
\end{abstract}

Keywords - Tecoma stans, NAA, rooting hormone, quick dip method, semi-hardwood

\section{INTRODUCTION}

Tecoma stans (L.) Juss. ex Kunthis a large shrub or small tree of Bignoniaceae family. It is an ornamental shrub growing for its lemon yellow, fragrant, funnel-flowers with pinnate leaves. It is native America (Bailey and Bailey, 1976 ${ }^{[1]}$. The flowers are in a raceme arrangement. The demand for the planting material for this yellow trumpet bush is very high and the difficulty existed in sexual reproduction due to Heterozygosity. Vegetative propagation is the only way for true-to-type multiplication when Heterozygosity acts as barrier for production of uniform planting materials. Simple and cost effective vegetative propagation method is stem cutting. The rooting ability and success percentage of stem cuttings depends on many factors such as variety, season, location, age of the mother plant, part of the plants used, nutrient status of the cutting, climatic conditions, aftercare etc. As well, rooting hormones used for stimulating quick and more roots on propagules plays an important role in multiplication through stem cuttings. Root induction through additional application of rooting hormone, though it present in plants, occupies a significant role in the field of plant propagation (Mukherjee et al., 1976) ${ }^{[6]}$.

Base of the stem cuttings treated with rooting hormone will induce more rooting compared to untreated one. Sometimes, rooting hormones are used in the propagation of species which will not root easily under normal conditions. Auxin is well known to improve rooting of different types of cuttings. The development of root primordium cells depends on the endogenous Auxins in the cutting and synergic composite such as a diphenol. These substances lead to the synthesis of ribonucleic acid (RNA), which act upon root primordium initiation (Hartmann et al., 2002) ${ }^{[4]}$. Synthetic Auxins are commonly used to improve rooting efficiency and quality of stem-cuttings. Treatment of cuttings with rooting hormones has been reported to improve rooting in many woody and semi woody species. Hence, the present study has been taken up to understand the method of propagation through semi-hardwood stem cutting of Tecoma stans along with the treatment of rooting hormone.

\section{EXPERIMENTAL METHODS OR METHODOLOGY}

The study was carried over at Institute of Agriculture, Tamil Nadu Agricultural University, Kumulur, Tiruchirappalli, Tamilnadu, India. The experiment design was laid out in Completely Randomized Block (CRBD) with 2 replications and seven treatments viz., Naphthalene Acetic Acid (NAA) - 500 ppm, 1000 ppm, 1500 ppm, 2000 ppm, 2500 ppm, $3000 \mathrm{ppm}$ and control (without any treatment) respectively. Semi-hardwood stem cuttings of $20 \mathrm{~cm}$ length, with minimum 3-4 nodes without leaves having pencil thickness were collected from healthy Tecoma stans mother plants. A slant cut was given at the basal end and a transverse cut at the top of each cutting. The basal end $(2.5-3.0 \mathrm{~cm}) \mathrm{of}$ the cuttings was dipped for 30 seconds with NAA solutions. Then, the treated cuttings were planted vertically in sterilized 
Vol. 8, Issue 8, August 2021

\section{DOI: $10.17148 /$ IARJSET.2021.88108}

inert sand media under mist chamber condition to promote rooting. All cuttings were maintained under mist chamber and watered regularly. Relative humidity in the mist chamber was maintained at $\geq 85 \%$ and temperature at $30 \pm 2{ }^{\circ} \mathrm{C}$. Further observations were recorded at 45 days after planting (DAP) on various shoot and root parameters such as days taken for sprouting, rooting percentage $(\%)$, number of buds sprouted, root length $(\mathrm{cm})$, shoot length $(\mathrm{cm})$ and number of leaves formed on cuttings. The inference was drawn after comparing the calculated $\mathrm{F}$ values with the tabulated $\mathrm{F}$ values at $5 \%(\mathrm{P}=0.05)$ level of significance. The estimates of mean, variance and standard error were done as per Panse and Sukhatme (1967) ${ }^{[7]}$.

\section{RESULTS AND DISCUSSION}

The result wereanalysed in this experiment, shows (as in table 1) significance on the parameters such as days for sprouting, rooting percentage and root length. But on accounting the effect on number of buds per cutting, shoot length, number of leaves per cutting; the results were not considerably significant. Cuttings of yellow trumpet bush had undergone minimum days of sprouting (9.90 days) when treated with NAA $3000 \mathrm{ppm}$. All the treatment were highly significant from control in days for sprouting but on par within each other. Rooting percentage of the cuttings also shows higher value in $3000 \mathrm{ppm}$ concentration (80.90\%). But it is on par with other concentrations such as $2500 \mathrm{ppm}$ (78.60\%), $2000 \mathrm{ppm}(71.60 \%), 1500(68.50 \%)$ and $1000(65.30 \%)$. This observation clearly denotes that, NAA treatment encourages quick sprouting and maximum rooting percentage of cuttings irrespective of concentrations. It is clear from the results that effect of root promotion through quick dipping of rooting hormone is directly proportionate to the concentration of rooting hormone treated. Our findings are in line with experimental reports of Hussain and Urbi (2016) ${ }^{[5]}$ on adventitious rooting in shoot cuttings of Andrographis paniculata. They stated that higher concentration of NAA resulted in an increased number of adventitious rooting per cutting. Similar reports were given by Raji and Osman (2012) ${ }^{[9]}$ and Dash et al., (2011) ${ }^{[2]}$ as that the higher dosages of auxins induced increased number of roots within a short time.

Maximum root length $(16.75 \mathrm{~cm})$ was recorded in $3000 \mathrm{ppm}$ concentration, followed by $2500 \mathrm{ppm}(15.90 \mathrm{~cm})$ and 2000 ppm $(13.57 \mathrm{~cm})$ which are on par with each other. Shenoy, $1992^{[11]}$ in Rosa damascena reported that the increase in root length over control may be due to the enhanced hydrolysis of carbohydrates, metabolites accumulation and cell division induced by Auxin. These results were in line with the findings of Patil et al., $1998^{[8]}$ in Jasminum sambac (Jasmine), Singh et al., 2010 ${ }^{[13]}$ in Bougainvillea glabra (bougainvillea), Grewal et al., 2005 ${ }^{[3]}$ in Dendranthema grandiflora cv. Snowball, Singh et al., $2013^{[12]}$ in Cestrum nocturnum (night jasmine) and Sharma, 2014 ${ }^{[10]}$ in Tagetes erecta (marigold).

Table 1: Effect of different concentrations of NAA on rooting of Tecoma stans

\begin{tabular}{|l|l|l|l|l|l|l|}
\hline Concentrations & $\begin{array}{l}\text { Days for } \\
\text { sprouting }\end{array}$ & $\begin{array}{l}\text { Rooting } \\
\text { percentage } \\
(\mathbf{\%})\end{array}$ & $\begin{array}{l}\text { Number of } \\
\text { buds per } \\
\text { cutting }\end{array}$ & $\begin{array}{l}\text { Root length } \\
\text { (cm) }\end{array}$ & $\begin{array}{l}\text { Shoot length } \\
\text { (cm) }\end{array}$ & $\begin{array}{l}\text { No. } \\
\text { leaves per } \\
\text { cutting }\end{array}$ \\
\hline $\mathbf{5 0 0} \mathbf{~ p p m}$ & 12.40 & 60.70 & 2.30 & 10.10 & 8.97 & 6.90 \\
\hline $\mathbf{1 0 0 0} \mathbf{~ p p m}$ & 12.30 & 65.30 & 2.40 & 11.70 & 9.50 & 7.20 \\
\hline $\mathbf{1 5 0 0} \mathbf{~ p p m}$ & 11.57 & 68.50 & 2.60 & 12.67 & 10.10 & 7.80 \\
\hline $\mathbf{2 0 0 0} \mathbf{~ p p m}$ & 11.55 & 71.60 & 2.90 & 13.57 & 10.05 & 7.80 \\
\hline $\mathbf{2 5 0 0} \mathbf{~ p p m}$ & 10.10 & 78.60 & 3.10 & 15.90 & 10.25 & 8.49 \\
\hline $\mathbf{3 0 0 0} \mathbf{~ p p m}$ & 9.90 & 80.90 & 3.45 & 16.75 & 10.71 & 8.70 \\
\hline Control & 15.50 & 35.60 & 2.10 & 6.60 & 7.50 & 6.30 \\
\hline Mean & 11.90 & 65.89 & 2.69 & 12.47 & 9.58 & 7.60 \\
\hline SE.d & 1.70 & 9.53 & 0.39 & 1.82 & 1.36 & 1.08 \\
\hline CD & 3.65 & 20.43 & 0.83 (NS) & 3.91 & 2.92 (NS) & 2.32 (NS) \\
\hline
\end{tabular}

\section{CONCLUSION}

On observing effect of NAA on rooting of Tecoma stans semi-hardwood stem cuttings, it is clear that rooting hormone NAA have the capacity to promote more rooting which results in quick sprouting and maximum rooting percentage. It is confined that quick dipping for 30 seconds with 3000 ppm of NAA will promote earlier rooting, maximum rooting percentage and improved root growth in Tecoma stans. 


\title{
International Advanced Research Journal in Science, Engineering and Technology
}

\author{
Vol. 8, Issue 8, August 2021
}

\section{DOI: $10.17148 / I A R J S E T .2021 .88108$}

\section{REFERENCES}

1. Bailey LH and Bailey EZ. "Hortus third: A concise dictionary of plants cultivated in the United States and Canada". Macmillan Publishing Co., New York. 1976.

2. Dash GK, Senapati SK and Rout GR. "Effect of auxins on adventitious root development from nodal cuttings of Saracaasoka (Roxb.) de Wilde and associated biochemical changes”. Journal of Horticulture and Forestry, 2011; 3(10): pp. 320-326.

3. Grewal HS, Kumar R, Chauhan R. Effect of IBA and NAA on rooting in chrysanthemum (Dendranthema grandifloraTzevlev) terminal cuttings. Journal of Ornamental Horticulture, 2005; 8(3):pp.230-232.

4. Hartmann HT, Kester DE, Davis FT and Geneve RL. Plant propagation: principles and practices, New Jersey: Prentice Hall, 2002.

5. Hossain MS and Urbi Z. Effect of naphthalene acetic acid on the adventitious rooting in shoot cuttings of Andrographis paniculata (Burm.f.) Wall. ex Nees: an important therapeutical herb. International Journal of Agronomy, 2016 ; Article ID: 1617543.

6. Mukherjee TP, Roy T and Bose TK. Standardization of propagation from cuttings under mist, II. Effect of rooting media on root formation in cutting of ornamental plants, Journal Punjab Hort. 1976; 16:pp. 153-156.

7. Panse VG andSukhatme PV. Statistical methods for agricultural workers. 3rd Ed. New Delhi: Indian Council of Agricultural Research, 1978.

8. Patil B and Kanamadi VC. Effect of growth regulators on the rooting of hardwood cuttings in jasmine. Advances in Forestry Research in India, 1998; 19: pp. 225-229.

9. Raji AA and Osman M. Effects of stem cutting types, position and hormonal factors on rooting in Stevia rebaudianaBertoni. Journal of Agricultural Science, 2012; 4(1): pp.49-57.

10. Nirsandh Ganesan; Vishwathikumaresan; Ramya Devi U. "Utilization Fuzzy Logic in Agriculture Sprinkler System". International Research Journal on Advanced Science Hub, 3, 4, 2021, 77-82. doi: 10.47392/irjash.2021.118

11. Mr. Vanlalmuana; Dr. Laldinliana. "Structure and Financial Performance of Primary Agricultural Credit Cooperative Societies in Mizoram". International Research Journal on Advanced Science Hub, 2, Special Issue ICARD 2020, 2020, 202-206. doi: 10.47392/irjash.2020.120

12. Sharma R. Study on the effect of Auxins on rooting, growth and flowering of African marigold (Tagetes erecta L.) propagated through stem cuttings, M. Sc., (Hort.) thesis. I.G.K.V., Raipur, 2014

13. Shenoy R. Influence of planting material and growth regulators on the rooting of stem cuttings in Rosa damascena Mill, M. Sc., (Hort.) Thesis submitted to the University of Agricultural Sciences, Bangalore, 1992.

14. Singh KK, Rawat V, Rawat JMS, Tomar YK and Kumar P. Effect of IBA and NAA concentrations on rooting in stem cuttings of Night queen (Cestrum nocturnum L) under sub-tropical valley conditions. Hort Flora Research Spectrum, 2013; 2(1):pp. 81-83.

15. Singh N, Singh BP and Singh HK. Effect of different concentrations of Indole Butyric Acid (IBA) on rooting potential and root growth of Bougainvillea stem cuttings. Journal of Ornamental Horticulture, 2010; 13(1): pp.41-44. 